\title{
EFEKTIVITAS PENERAPAN MODEL PEMBELAJARAN QUANTUM TEACHING UNTUK MENINGKATKAN PEMAHAMAN KONSEP MATEMATIKA SISWA PADA MATERI TRIGONOMETRI
}

\section{THE EFFECTIVENESS OF APPLYING QUANTUM TEACHING MODEL TO IMPROVE THE STUDENTS' MATHEMATICAL CONCEPT UNDERSTANDING IN TRIGONOMETRY}

\author{
Murlia'), Rosdiana'), Siti Zuhaerah Thalhah $^{3),}$ Munawarah ${ }^{4)}$ \\ 1,2,3)IAIN Palopo, 4)IAIN Bone

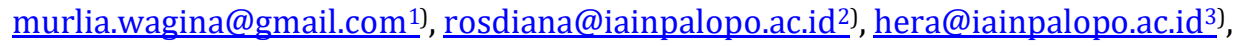 \\ munawarahr@gmail.com $\left.{ }^{4}\right)$
}

\begin{abstract}
Abstrak
Penelitian ini bertujuan untuk mengetahui pemahaman konsep matematika pada materi trigonometri siswa sebelum penerapan model pembelajaan quantum teaching, pemahaman konsep matematika pada materi trigonometri siswa setelah penerapan model pembelajaan quantum teaching, dan model pembelajaran quantum teaching efektif untuk meningkatkan pemahaman konsep matematika pada materi trigonometri siswa. Penelitian ini adalah penelitian eksperimen dengan model one-group pre-test - post-test design yang terdiri dari dua tahap yaitu siswa diberikan tes sebelum diberi perlakuan (pretest) dan diberikan tes setelah diberi perlakuan (post-test). Instrumen yang digunakan dalam penelitian ini adalah instrumen dalam bentuk uraian yang jumlahnya 4 soal terdiri dari pre-test dan post-test. Kemudian yang menjadi sampel dalam penelitian ini. Penelitian ini bertujuan adalah siswa kelas XI SMA Negeri 2 Palopo. Hasil penelitian berdasarkan data hasil pre-test siswa menunjukkan bahwa tingkat pemahaman konsepnya masih dibawah rata-rata atau $48.25 \%$ dengan kategori kurang, sedangkan setelah melakukan model pembelajaran quantum teaching dengan memberikan post-test terlihat pemahaman konsep siswa di atas rata-rata atau $84.25 \%$ dengan kategori tinggi. Sehingga dapat disimpulkan bahwa model pembelajaran quantum teaching efektif untuk meningkatkan pemahaman konsep matematika pada materi trigonometri siswa kelas XI SMA Negeri 2 Palopo.
\end{abstract}

Kata Kunci: quantum teaching, pemahaman konsep, trigonometri

\begin{abstract}
This study aims to understand: Understanding of mathematical concepts in the trigonometric material of students before applying the learning models for quantum teaching models. Understanding of mathematical concepts in the trigonometry material of students after the application of quantum teaching learning models. This research is an experimental study with one-group pre-test model - post-test design consisting of two students who are given a test before being given training (pre-test) and given a test after being given training (post- test). The instrument used in this study was an instrument in the form of a description inviting 4 questions consisting of pre-test and post-test. Then the subjects in this study were students of class XI of SMA Negeri 2 Palopo. The results of the study are based on students 'pre-test results showing the level of concept understanding is still below average or $48.25 \%$ with less categories, whereas after conducting a quantum learning model of teaching by giving a post-test it appears that students' concept understanding is above average or $84.25 \%$ with a high category. The quantum learning
\end{abstract}


model is effective for improving understanding of mathematical concepts in the trigonometry material for grade XI students of SMA Negeri 2 Palopo.

Keywords: quantum teaching, understanding concepts, trigonometry

How to Cite: Murlia, Rosdiana, Thalhah, S. Z., \& Munawarah. (2020). Efektivitas model pembelajaran quantum teaching untuk meningkatkan pemahaman konsep matematika siswa pada materi trigonometri. Al asma: Journal of Islamic Education, 2(1), 142-150.

\section{PENDAHULUAN}

Pendidikan pada dasarnya merupakan upaya untuk memberikan pengetahuan, wawasan, keterampilan, dan keahlian tertentu kepada manusia guna mengembangkan bakat serta kepribadiannya. Dengan pendidikan manusia bisa mengembangkan dirinya untuk menghadapi perubahan yang terjadi akibat adanya kemajuan ilmu pengetahuan dan teknologi.

Pendidikan artinya suatu proses pengubahan sikap dan tata laku seseorang atau kelompok orang dalam usaha mendewasakan manusia melalui upaya pengajaran dan latihan, proses perbuatan dan cara mendidik (Yusuf, 2018). Dalam Undang-Undang tentang Sistem Pendidikan Nasional No. 20 tahun 2003, pendidikan adalah usaha sadar dan terencana untuk mewujudkan suasana belajar dan proses pembelajaran agar peserta didik secara aktif mengembangkan potensi dirinya untuk memiliki kekuatan spiritual keagamaan, pengendalian diri, kepribadian, kecerdasan akhlak mulia, serta keterampilan yang diperlukan dirinya, masyarakat, bangsa dan negara (Ningrum, 2017). Ilmu menempati kedudukan yang sangat penting dalam pendidikan, hal ini terlihat dari banyaknya ayat Al-Qur'an yang memandang orang berilmu dalam posisi yang tinggi dan mulia, sebagaimana firman Allah Swt. dalam QS. Al-Mujaadilah/58:11 yang menjelaskan bahwa orang beriman dan berilmu akan memperoleh kedudukan yang tinggi. Dalam menuntut ilmu ada bermacam-macam cabang ilmu pengetahuan, salah satunya adalah ilmu matematika.

Matematika merupakan bidang studi yang dipelajari oleh semua jenjang pendidikan, mulai dari SD sampai SMA dan juga Perguruan Tinggi. Namun pada kenyataannya pemahaman konsep siswa dalam pembelajaran matematika merupakan salah satu masalah yang dihadapi pendidikan di Indonesia saat ini. Pemahaman konsep merupakan kompetensi yang ditunjukkan siswa dalam memahami konsep dan melakukan prosedur secara akurat, efisien dan tepat. Pemahaman konsep bertujuan untuk mengetahui sejauh mana peserta didik mampu menerima dan memahami konsep dasar yang telah diterima dari pendidik.

Berdasarkan hasil observasi awal pada tanggal 19 oktober 2018 di kelas XI IPA SMA Negeri 2 Palopo, masih banyak siswa yang belum memahami konsep dalam pembelajaran matematika disebabkan saat awal belajar matematika guru kurang menanamkan konsep dan siswa yang kurang dalam memperhatikan materi yang diajarkan. Masalah-masalah yang dialami oleh siswa tersebut berdampak pada hasil belajar dan pemahaman konsep siswa yang kurang maksimal. Terlihat pada ketuntasan hasil belajar siwa kelas XI IPA pada ulangan harian matematika materi trigonometri semester ganjil. Sebagian besar siswa belum mencapai Kriteria Ketuntasan Minimum (KKM) yang ditetapkan yaitu 70. Ketidaktuntasan hasil belajar tersebut dapat dilihat dari 
hasil belajar siswa pada ulangan harian matematika materi trigonometri semester ganjil kelas XI IPA 1 dan XI IPA 2 tahun pelajaran 2018/2019 yang dipaparkan pada Tabel 1.

Tabel 1. Data nilai ulangan Harian Matematika Materi Trigonometri Semester Ganjil Kelas XI IPA 1 dan XI IPA 2 SMA Negeri 2 Palopo Tahun Ajaran 2018/2019.

\begin{tabular}{clcccc}
\hline Nilai & KKM & XI IPA 1 & Persentase & XI IPA 2 & Persentase \\
\hline$\geq 70$ & Tuntas & 3 & $9 \%$ & 1 & $3 \%$ \\
$\leq 70$ & Belum Tuntas & 30 & $91 \%$ & 29 & $97 \%$ \\
\hline Jumlah & & 33 & $100 \%$ & 30 & $100 \%$ \\
\hline
\end{tabular}

Sumber: Guru matematika peminatan Drs.Hamid.,M.Si

Berdasarkan Tabel 1, dapat diketahui bahwa kriteria ketuntasan minimal yang telah ditentukan adalah 70. Di kelas XI IPA 1 terdiri dari 33 siswa, persentase siswa yang tuntas sebesar 9\% dan siswa yang belum tuntas sebesar 91\% dan untuk kelas XI IPA 2 berjumlah 30 siswa, persentase siswa yang tuntas 3\% dan siswa yang tidak tuntas $97 \%$. Dapat disimpulkan bahwa nilai ulangan harian semester ganjil siswa untuk mata pelajaran matematika kelas XI IPA 1 dan XI IPA 2 SMA Negeri 2 Palopo masih banyak yang belum tuntas. Oleh karena itu, peneliti menerapkan model pembelajaran quantum teaching pada pembelajaran matematika yang tepat agar siswa memahami konsep dari pelajaran matematika. Ada banyak macam model pembelajaran matematika yang tumbuh sebagai inovasi yang diharapkan sesuai dengan tantangan pendidikan sekarang dan mendatang. Dalam hal ini peneliti memilih model pembelajaran quantum teaching.

Pengertian model pembelajaran merupakan landasan praktik pembelajaran hasil penurunan teori psikologi pendidikan dan belajar, yang dirancang berdasarkan proses analisis yang diarahkan pada implementasi kurikulum dan implikasinya pada tingkat operasional di depan kelas (Ali Hamzah, 2014). Dengan adanya suatu model dan pembelajaran pendidik mampu melihat situasi pada saat mengajar apakah model dari pembelajaran yang dilakukan sesuai dan mampu meningkatkan proses pemahaman konsep siswa itu sendiri.

Quantum teaching berasal dari dua kata yaitu "Quantum" yang berarti interaksi yang mengubah energi menjadi cahaya dan "Teaching" yang berarti mengajar, dengan demikian quantum teaching adalah orkestrasi bermacam-macam interaksi yang ada di dalam dan di sekitar momen belajar. Interaksi-interaksi ini mencakup unsur-unsur untuk belajar efektif yang memengaruhi kesuksesan siswa. Interaksi-interaksi ini mengubah kemampuan dan bakat alamiah siswa menjadi cahaya yang akan bermanfaat bagi mereka sendiri dan bagi orang lain(Porter et. al., 2000). Demikian pula, yang dikemukakan oleh A'ala dalam Yahya (2017), bahwa quantum teaching merupakan orkestrasi bermacammacam interaksi yang ada di dalam dan disekitar momen belajar.

Model pembelajaran quantum teaching adalah model yang digunakan dalam rancangan penyajian dalam belajar yang dirangkai menjadi sebuah paket yang multisensori, multi-kecerdasan, dan kompatibel dengan otak, mencakup petunjuk spesifik untuk menciptakan lingkungan belajar yang efektif, merancang kurikulum, menyampaikan isi, dan memudahkan proses belajar (Daryanto \& Karim, 2017). Oleh karena itu, model pembelajaran quantum teaching adalah suatu model pembelajaran yang dapat menciptakan suasana belajar yang meriah dan menyenangkan bagi siswa, yang 
membuat siswa untuk berperan aktif dalam proses belajar sehingga dapat meningkatkan pemahaman konsep pada siswa.

Quantum teaching memiliki lima prinsip, atau kebenaran tetap. Prinsip-prinsip ini mempengaruhi seluruh aspek quantum teaching. Prinsip-prinsip tersebut adalah: (1) Segalanya berbicara; segalanya dari lingkungan kelas hingga bahasa tubuh guru, dari kertas yang guru bagikan hingga rancangan pelajaran guru, semuanya mengirim pesan tentang belajar. (2) Segalanya bertujuan; semuanya yang terjadi dalam pengubahan guru mempunyai tujuan pembelajaran. (3) Pengalaman sebelum pemberian nama; otak berkembang pesat dengan adanya rangsangan kompleks, yang akan menggerakkan rasa ingin tahu. Oleh karena itu, proses belajar paling baik terjadi ketika siswa telah mengalami informasi sebelum mereka memperoleh nama untuk apa yang mereka pelajari. (4) Akui setiap usaha; Belajar mengandung resiko. Belajar berarti melangkah keluar dari kenyaman. Pada saat siswa mengambil langkah ini, mereka patut mendapat pengakuan atas kecakapan dan kepercayaan diri mereka. (5) Jika layak dipelajari, maka layak pula dirayakan; perayaan adalah sarapan pelajar juara. Perayaan memberikan umpan balik mengenai kemajuan dan meningkatkan asosiasi emosi positif dengan belajar (Thobroni, 2017).

Pemahaman pada dasarnya berasal dari kata "paham" yang mengandung makna benar-benar mengerti". Pemahaman dalam Taksonomi Bloom merupakan salah satu aspek dalam ranah kognitif. Bloom dalam bukunya Ruseffendi membagi aspek pemahaman menjadi tiga macam pemahaman yaitu: translation, interpretation, dan ekstrapolasi. Pengubahan (translation), adalah kemampuan memahami ide yang dinyatakan dengan cara lain dari pernyataan aslinya. Misalnya mampu mengubah (translation) soal cerita ke dalam kalimat matematis, pemberian arti (interpretation) misalnya mampu mengartikan suatu kesamaan, dan memperkirakan (extrapolation) (Alamsyah, 2018). Menurut Duffin \& Simpson dalam Kesumawati (2008), pemahaman konsep sebagai kemampuan siswa untuk: a) menjelaskan konsep, dapat diartikan siswa mampu untuk mengungkapkan kembali apa yang telah dikomunikasikan kepadanya, b) menggunakan konsep pada berbagai situasi yang berbeda, dan c) mengembangkan beberapa akibat dari adanya suatu konsep. Dengan demikian, pemahaman konsep adalah penguasaan sejumlah materi pembelajaran, dimana siswa tidak hanya mengenal dan mengetahui, tapi mampu mengungkapkan kembali dalam bahasa yang mudah dimengerti serta mampu mengaplikasikannya. Pemahaman konsep merupakan bagian yang sangat penting dalam pembelajaran matematika.

Pemahaman konsep matematika memberikan pengertian bahwa materi-materi yang diajarkan kepada siswa bukan hanya sebagai hafalan, tetapi dengan pemahaman siswa lebih mengerti akan konsep materi pelajaran itu sendiri. Pemahaman tersebut ditandai dengan kemampuan dalam menjelaskan dengan kata-kata sendiri, membandingkan, membedakan, dan mempertentangkan ide yang diperoleh dengan ide yang baru (Anas \& Fitriani, 2018). Oleh karena itu, pemahaman konsep matematika merupakan salah satu kecakapan atau kemahiran matematika yang diharapkan dapat tercapai dalam belajar matematika yaitu dengan menunjukkan pemahaman konsep matematika yang dipelajarinya, menjelaskan keterkaitan antarkonsep dan mengaplikasikan konsep atau algoritma secara luwes, akurat, efisien, dan tepat dalam pemecahan masalah. 
Siswa dikatakan memahami konsep jika siswa mampu mendefinisikan konsep, mengidentifikasi dan memberi contoh atau bukan contoh dari konsep, mengembangkan kemampuan koneksi matematik antarberbagai ide, memahami bagaimana ide-ide matematika saling terkait satu sama lain sehingga terbangun matematika. Siswa dikatakan memahami prosedur jika mampu mengenali prosedur (sejumlah langkahlangkah dari kegiatan yang dilakukan) yang didalamnya termasuk aturan algoritma atau proses menghitung yang benar, pemahaman menyeluruh, dan menggunakan matematik dalam konteks di luar.

Adapun hasil penelitian yang dilakukan oleh Hasnaeni (2013) dengan judul "Penerapan Strategi Pembelajaran Quantum Teaching Untuk Meningkatkan Hasil Belajar Matematika Siswa Kelas VIII di Madrasah Tsanawiyah Madani UIN Alauddin Pao- Pao Kabupaten Gowa" menunjukkan bahwa strategi pembelajaran quantum teaching dapat merubah pola belajar siswa dari kurang termotivasi untuk belajar menjadi lebih termotivasi, dari yang kurang aktif menjadi aktif dalam mempelajari matematika. Hasil yang diperoleh dari penerapan strategi pembelajaran quantum teaching pada kelas VIIIB MTs. Madani UIN Alauddin Pao-Pao Kabupaten Gowa yaitu skor rata-rata belajar matematika pada siklus I yaitu 63,68 sedangkan pada siklus ke II yaitu 72,36. Adapun persentase ketuntasan pada siklus I yaitu 63,64\% sedangkan pada siklus ke II yaitu 90,91\%, sehingga dapat disimpulkan bahwa terdapat peningkatan hasil belajar matematika siswa kelas VIIIB MTs. Madani (Hasnaeni, 2013).

Selain itu, penelitian yang dilakukan oleh Dhian Arista Istikomah \& Padrul Jana (2018) mengenai "Kemampuan Pemahaman Konsep Matematis Mahasiswa melalui Pendekatan Pembelajaran Saintifik dalam Perkuliahan Aljabar Matriks". Hasil penelitian menunjukkan bahwa pendekatan saintifik sesuai untuk mengembangkan kemampuan pemahaman konsep matematis mahasiswa. Hal ini dapat dilihat dari skor kemampuan pemahaman konsep dimana tidak ada mahasiswa yang berada dalam kategori kurang, serta $89,29 \%$ berada dalam kategori tinggi dan sedang. Dari hasil tes kemampuan pemahaman konsep juga didapatkan bahwa hasil nilai terendah adalah dalam kategori indikator menggunakan, memanfaatkan, dan memilih prosedur atau operasi tertentu (Istikomah \& Jana, 2018). Selanjutnya hasil penelitian yang dilakukan oleh Santoso (2015) dengan judul "Efektivitas Penerapan Quantum Teaching terhadap Hasil Belajar Elektronika Dasar pada Siswa Kelas X Jurusan Teknik Ototronik SMK Negeri 1 Sayegan" menunjukkan bahwa model quantum teaching lebih efektif dibandingkan dengan model konvensional pada materi gerbang logika dasar jurusan teknik ototronik SMK Negeri 1 Seyegan (Santoso, 2015).

\section{METODE PENELITIAN}

Jenis penelitian ini adalah penelitian kuantitatif dengan metode eksperimen karena pada penelitian ini diberikan suatu perlakuan (treatment) untuk mengetahui hubungan antara perlakuan tersebut dengan aspek tertentu yang akan diukur. Eksperimen yang dilakukan bermaksud untuk mengetahui penerapan model pembelajaran quantum teaching terhadap pemahaman konsep matematika pada materi trigonometri analitika siswa kelas XI SMA Negeri 2 Palopo. Populasi pada penelitian ini adalah siswa kelas XI SMA Negeri 2 Palopo tahun ajaran 2018/2019 dengan sampel kelas XI IPA 1 sebagai kelas eksperimen. 
Teknik pengumpulan data yang digunakan pada penelitian ini adalah tes berupa tes hasil belajar formatif, observasi, dan dokumentasi. Tes hasil belajar formatif berbentuk uraian tentang materi yang telah dipelajari oleh siswa. Observasi digunakan untuk mengetahui apakah penerapan model pembelajaran quantum teaching ini sesuai dengan yang direncanakan. Dokumentasi digunakan untuk mengumpulkan data yang menunjang penelitian seperti nilai ulangan harian dan data-data pendukung khususnya yang dibutuhkan dalam gambaran umum SMA Negeri 2 Palopo.

Analisis data pada penelitian ini menggunakan rumus statistic parametris dengan uji t berdasarkan uji normalitas dan homogenitas untuk mengetahui adakah pengaruh penerapan model pembelajaran quantum teaching terhadap pemahaman konsep matematika siswa di kelas XI SMA Negeri 2 Palopo.

\section{HASIL DAN PEMBAHASAN}

Dalam penelitian ini, data yang dikumpulkan adalah data tentang penggunaan model pembelajaran quantum teaching untuk meningkatkan pemahaman konsep siswa. Selanjutnya untuk mencapai tujuan penelitian, data yang diperoleh dianalisis menggunakan uji t. Data yang terkumpul dalam penelitian ini diperoleh dari pre-test yaitu hasil tes sebelum menggunakan model pembelajaran quantum teaching, dan post-test yaitu hasil tes setelah menggunakan model pembelajaran quantum teaching.

Hasil kemampuan pemahaman konsep pre-test siswa memiliki skor rata-rata kemampuan pemahaman konsep matematis adalah 19,3 dari skor ideal 40 atau 48,26\% dengan kategori rendah. Untuk skor rata-rata per aspek kemampuan pemahaman konsep, disajikan sebagai berikut: (a) Aspek kemampuan menyatakan ulang sebuah konsep adalah 2.4 dari skor ideal 10 atau 24\% dengan kategori rendah. (b) Aspek mengklasifikasikan objek menurut sifat-sifat tertentu sesuai dengan konsepnya adalah 5,6 dari skor ideal 10 atau 56\% dengan kategori sedang. (c) Aspek mengembangkan syarat perlu atau syarat cukup dari suatu konsep adalah 5,5 dari skor ideal 10 atau 55\% dengan kategori sedang. (d) Aspek menggunakan dan memanfaatkan serta memilih prosedur atau operasi tertentu adalah 5,7 dari skor ideal 10 atau 57\% dengan kategori sedang.

Pada data post-test menunjukkan bahwa hasil kemampuan pemahaman konsep post-test siswa memiliki skor rata-rata kemampuan pemahaman konsep matematis adalah 33,809 dari skor ideal 40 atau 84,52\% dengan kategori tinggi. Untuk skor rata-rata per aspek kemampuan pemahaman konsep, yaitu: (a) Aspek kemampuan menyatakan ulang sebuah konsep adalah 5,77dari skor ideal 10 atau 57,7\% dengan kategori sedang. (b) Aspek mengklasifikasikan objek menurut sifat-sifat tertentu sesuai dengan konsepnya adalah 9,92 dari skor ideal 10 atau 99,2\% dengan kategori tinggi. (c) Aspek mengembangkan syarat perlu atau syarat cukup dari suatu konsep adalah 9,92 dari skor ideal 10 atau 99,2\% dengan kategori tinggi. (d) Aspek menggunakan dan memanfaatkan serta memilih prosedur atau operasi tertentu adalah 8,19 dari skor ideal 10 atau 81,9\% dengan kategori tinggi.

Setelah mengetahui pemahaman konsep siswa, selanjutnya dilakukan uji normalitas data dan uji homogenitas data. Dalam uji normalitas dilakukan sebanyak dua kali, yang pertama uji normalitas pada data hasil pre-test dan uji yang kedua pada data 
hasil post-test. Pada uji normalitas untuk data hasil pre-test di peroleh nilai $\mathrm{X}_{2}$ hitung $=-20.5$ dan nilai $X^{2}$ tabel $(0,05 ; 32)=46.194$. Karena bila chi kuadrat hitung $(-20.5)$ lebih kecil dari nilai chi kuadrat tabel (46.194), sehingga distribusi data hasil pre-test dinyatakan berdistribusi normal pada taraf signifikan $5 \%$. Kemudian pada uji normalitas hasil post-test diperoleh nilai $\mathrm{X}^{2} \mathrm{hitung}=-31.4$ dan nilai $\mathrm{X}^{2}$ tabel $(0,05 ; 32)=46.194$. Karena nilai chi kuadrat hitung (-31.4) lebih kecil dari nilai chi kuadrat tabel (46.194), sehingga distribusi data hasil post-test juga dinyatakan berdistribusi normal, maka untuk analisis data dapat digunakan statistik parametrik. Selanjutnya untuk uji homogenitas dengan menggunakan uji $\mathrm{f}$ antara hasil pre-test dengan post-test diperoleh nilai $\mathrm{F}_{\text {hitung }}=1.2$ dan nilai $F_{\text {tabel }}=1.86$. Karena nilai $F_{\text {hitung }}$ lebih kecil dari Ftabel pada taraf signifikan 5\% sehingga disimpulkan data homogen. Berdasarkan hasil analisis dengan menggunakan uji $t$ diperoleh bahwa $t_{\text {hitung }}-5,2$. Nilai $t_{\text {hitung }}$ tersebut selanjutnya dibandingkan dengan $t_{\text {tabel }}$ $(\mathrm{dk})=\mathrm{n}-1=33-1=32$. Berdasarkan $\mathrm{dk}=32$, untuk kesalahan $5 \%$ maka nilai $\mathrm{t}_{\text {tabel }}=$ 2,037 .

Berdasarkan penelitian ini, diketahui bahwa kondisi awal kemampuan pemahaman siswa kurang baik. Selanjutnya setelah diberikan perlakuan menggunakan model pembelajaran quantum teaching didapatkan hasil bahwa terdapat perbedaan model pembelajaran quantum teaching untuk meningkatkan pemahaman konsep matematika siswa kelas XI IPA 1. Terdapat peningkatan nilai post-test dari nilai pre-test, sehingga dapat diketahui bahwa pembelajaran menggunakan model pembelajaran quantum teaching memiliki hasil belajarnya lebih efektif. Hal tersebut berdasarkan hasil perhitungan rata-rata nilai post-test 33,809 sedangkan untuk hasil rata-rata pre-test 19,3. Kategori aktivitas siswa dikatakan efektif jika berada minimal pada kategori baik yaitu $50 \%$. Adapun perolehan hasil observasi aktivitas siswa, memiliki skor ideal 4,0 atau 100\% dalam penelitian ini menunjukkan bahwa rata-rata yang diperoleh adalah 3,87 atau 96\% yang selisihnya dari skor ideal adalah 0,13 atau $4 \%$. Ini menunjukkan bahwa aktivitas siswa dalam pemahaman konsep menggunakan model pembelajaran quantum teaching dalam kategori sangat baik dan sangat efektif dalam proses pembelajaran. Penggunaan model pembelajaran quantum teaching pada materi trigonometri dapat meningkatkan pemahaman konsep siswa menjadi lebih efektif karena mampu membuat suasana lebih menyenangkan dalam proses pembelajaran.

Adapun hasil penelitian yang dilakukan oleh Aprilia Setianingrum (2013) yang dilaksanakan di SMP Negeri 3 Rembang dapat disimpulkan bahwa model pembelajaran quantum teaching efektif terhadap kemampuan berpikir kreatif peserta didik pada materi segiempat dengan mencapai Kriteria Ketuntasan Minimal pada mata pelajaran matematika yaitu 70 dan hasil penelitian dari jurnal yang dilakukan oleh Angga Murizal, Yarman, dan Yerizon (2012) bahwa kemampuan pemahaman konsep matematis siswa yang belajar dengan model pembelajaran quantum teaching lebih baik daripada kemampuan pemahaman konsep matematis siswa yang belajar dengan pembelajaran konvensional di kelas VIII SMPN 3 Batusangkar. 


\section{SIMPULAN}

Berdasarkan penelitian yang telah dilakukan, maka dapat disimpulkan bahwa: (1) Pemahaman konsep matematika siswa kelas XI SMA Negeri 2 Palopo sebelum diterapkan model pembelajaran quantum teaching sangat rendah. (2) Pemahaman konsep matematika siswa kelas XI SMA Negeri 2 Palopo setelah diterapkan model pembelajaran quantum teaching mengalami peningkatan pemahaman konsep siswa dibanding dengan sebelumnya. (3) Terdapat perbedaan secara signifikan, nilai hasil tes siswa sebelum menggunakan model pembelajaran quantum teaching dan sesudah menggunakan model pembelajaran quantum teaching. Dari perbedaan tersebut model pembelajaran quantum teaching sangat efektif untuk meningkatkan pemahaman konsep matematika siswa. Setelah pembelajaran matematika menggunakan model pembelajaran quantum teaching, nilai hasil tes siswa meningkat, ini berarti pemahaman konsep tentang materi trigonometri siswa meningkat. Maka dari itu, siswa mengalami peningkatan setelah diterapkannya model pembelajaran quantum teaching serta aktivitas siswa memiliki kriteria sangat baik dalam proses pembelajaran menggunakan model pembelajaran quantum teaching.

\section{DAFTAR PUSTAKA}

Alamsyah, M. (2018). Analisis pemahaman konsep matematika pada siswa kelas VIII MTsN Balang-balang Kab. Gowa (Universitas Islam Negeri Alauddin Makassar). Retrieved from http://repositori.uin-alauddin.ac.id/8514/

Ali Hamzah, M. (2014). Perencanaan dan Strategi Pembelajaran Matematika. Jakarta: Raja Grafindo Persada.

Anas \& Fitriani. (2018). Penerapan model pembelajaran react dalam peningkatan pemahaman konsep siswa. Al-Khwarizmi: Jurnal Pendidikan Matematika Dan Ilmu Pengetahuan Alam, 6(2). https://doi.org/10.24256/jpmipa.v6i2.338

Daryanto \& Karim. (2017). Pembelajaran Abad 21. Yogyakarta: Gava Media.

Desrianti, D. (2019)."Penerapan model pembelajaran quantum teaching untuk meningkatkan kemampuan pemahaman konsep matematis siswa SMP/MTs". https://repository.arraniry.ac.id/id/eprint/7231/1/SKRIPSI\%20\%28WORD\%20 GABUNGAN\%29.pdf.

Dwiyani, M, dkk. "Efektifitas pembelajaran matematika dengan model quantum teaching (qt) ditinjau dari kreativitas belajar siswa kelas VIII SMP N 2 Turi". http://repository.upy.ac.id/267/1/Artikel\%20Monita\%20Dwiyani\%20\%281114 4 100135\%29.pdf.

Hasnaeni. (2013). Penerapan strategi pembelajaran quantum teaching untuk meningkatkan hasil belajar matematika siswa kelas VIII di Madrasah Tsanawiyah Madani UIN Alauddin Pao-Pao Kabupaten Gowa (UIN Alauddin Makassar). Retrieved from http://repositori.uin-alauddin.ac.id/2414/1/HASNAENI.pdf.

Istikomah, D. A., \& Jana, P. (2018). Kemampuan pemahaman konsep matematis mahasiswa melalui pendekatan pembelajaran saintifik dalam perkuliahan aljabar matriks. Prosiding Seminar Nasional Pendidikan Matematika Etnomatnesia. Retrieved from http://jurnal.ustjogja.ac.id/index.php/etnomatnesia/article/view/2438. 
Kesumawati, N. (2008). Pemahaman konsep matematik dalam pembelajaran matematika. Prosiding Seminar Nasional Matematika Dan Pendidikan Matematika. Retrieved from https://eprints.uny.ac.id/6928/

Murizal, Angga, dkk. (2012).“Pemahaman konsep matematis dan model pembelajaran quantum teaching," jurnal pendidikan matematika 1, no. 1 (2012).

Ningrum, R. S. (2017). Pengaruh penerapan model quantum teaching terhadap hasil belajar matematika siswa kelas IV SD Negeri 06 Metro Barat. Universitas Lampung Bandar Lampung.

Porter et. al., B. De. (2000). Quantum Teaching Orchestrating Student Succes. Boston: Allyn and Bacon.

Santoso, F. (2015). Efektivitas penerapan quantum teaching terhadap hasil belajar elektronika dasar pada siswa kelas X Jurusan Teknik Ototronik SMK Negeri 1. Jurnal Elektronik Pendidikan Teknik Elektronika, 4(8). Retrievedfrom http://journal.student.uny.ac.id/ojs/index.php/elektro- nika/article/view/2058

Setianingrum, A. (2013)."Keefektifan model pembelajaran quantum teaching terhadap kemampan berfikir kreatif peserta didik pada materi pokok segiempat, oleh: Aprilia Setianingrum4101409073.pdf," diakses 3 September 2018, http:// lib.unnes.ac.id/ 18960/ 1/ 4101409073.pdf.

Thobroni, M. (2017). Belajar dan Pembelajaran. Yogyakarta: Ar Ruzz Media.

Yahya, H. (2017). Pengaruh penerapan model pembelajaran quantum teaching terhadap hasil belajar biologi siswa SMA Islam Terpadu Al-Fityan Gowa. Jurnal Biotek, 5(1). https://doi.org/10.24252/jb.v5i1.3455

Yasmin, S. (2019)." Pengaruh penerapan model pembelajaran quantum teaching terhadap kemampuan pemahaman konsep matematis berdasarkan self-efficacy siswa Sekolah Menengah Pertama". http://repository.uin-suska.ac.id/25263/2/ SKRIPSI\%20SYIFA\%20YASMIN.pdf.

Yusuf, M. (2018). Pengantar Ilmu Pendidikan. Palopo: Lembaga Penerbitan STAIN (LPS) STAIN Palopo. 